\title{
HUBUNGAN HUKUM PERUSAHAAN INDUK BERBENTUK PERSEROAN TERBATAS DENGAN ANAK PERUSAHAAN BERBENTUK PERSEKUTUAN KOMANDITER \\ Oleh
}

Ni Made Pratiwi Dharnayanti*

NIM: 1492461012

Mahasiswa Program Magister Kenotariatan Universitas Udayana email : pratiwidharnayanti@gmail.com

Pembimbing I : Prof. Dr. Yohanes Usfunan, Drs., SH., MH** Pembimbing II : Dr. I Made Sarjana,SH.,MH***

\section{Abstrak}

Kepemilikan perusahaan induk atas saham pada anak perusahaan dalam jumlah tertentu memberi kewenangan kepada perusahaan induk untuk bertindak sebagai pimpinan sentral yang mengendalikan anak perusahaan. Namun hal ini menjadi permasalahan apabila bentuk anak perusahaan bukan berstatus sebagai badan hukum, yaitu Persekutuan Komanditer karena dalam isi Pasal 84 ayat (2) huruf b Undang-Undang No. 40 Tahun 2007 tentang Perseroan Terbatas maupun peraturan perundangan lainnya belum ada yang memuat tentang pengaturan hubungan hukum perusahaan induk yang berbentuk badan ke anak perusahaan yang bukan berbentuk badan hukum.

Berdasarkan kondisi tersebut, maka permasalahan yang dapat diangkat dalam penelitian ini adalah (1) Apakah yang menjadi dasar timbulnya hubungan hukum antara perusahaan induk yang berbentuk PT dengan anak perusahaan yang berbentuk $C V$, dan (2) Bagaimanakah akibat hukum dari hubungan hukum antara perusahaan induk yang berbentuk PT dengan anak perusahaan yang berbentuk $C V$.

Berangkat dari adanya kekosongan norma yang terdapat pada Pasal 84 ayat (2) huruf b UUPT terbaru, maka penelitian ini menggunakan penelitian hukum normatif. Penelitian ini menggunakan pendekatan perundang-undangan dan pendekatan analisis konsep hukum. Sumber bahan hukum dalam penelitian ini terdiri dari bahan hukum primer, sekunder dan tertier. Teknik pengumpulan bahan hukum menggunakan sistem kartu.. Teknik analisis bahan hukum yang digunakan adalah teknik deskriptif, teknik interpretatif, teknik evaluatif, teknik sistematif dan teknik argumentatif.

Hasil penelitian ini menunjukkan bahwa (1) dasar timbulnya hubungan hukum antara perusahaan induk yang berbentuk $P T$ dengan anak perusahaan yang berbentuk $C V$ terjadi karena adanya kepemilikan saham CV dari PT sebagai perusahaan induk, sehingga PT dapat menggunakan hak suaranya dalam RUPS untuk menetapkan kebijakan bagi CV sebagai anak perusahaan, mengangkat anggota direksi/dewan pengawas dalam $P T$ sebagai perusahaan induk sebagai direktur utama atau pengawas dalam $C V$, melakukan perjanjian hak bersuara dengan $C V$ dan melakukan kontrak kendali terhadap CV sebagai anak perusahaan; dan (2) akibat hukum dari hubungan hukum antara perusahaan induk yang berbentuk $P T$ dengan anak perusahaan yang berbentuk CV apabila ditinjau dari prinsip limited liability yang terdapat dalam Pasal 3 ayat (1) UUPT terbaru, maka dominasi antara PT terhadap $C V$ tidak melahirkan tanggung jawab hukum bagi PT dalam hubungan hukum yang terjadi dengan pihak ketiga, namun apabila PT terbukti melakukan indikasi-indikasi penyimpangan pada laporan keuangan dalam hubungan hukumnya dengan CV sebagai anak perusahaan, maka PT dapat dikenakan sanksi berupa denda atau pidana terhadap perbuatannya tersebut.

Kata Kunci: Perusahaan Induk, Anak Perusahaan, Hubungan Hukum.

\section{Abstract}

Ownership of parent company in its subsidiaries in the number of certain shares authorize the parent company to act as a central leader that controls the subsidiary. However, this is an issue when the form of subsidiaries not existed as a legal entity, such as $C V$. There's no legal relationship arrangements for parent company that incorporated to a subsidiary which is not a legal entity for the content of Article 84 paragraph (2) letter b of Law No. 40 of 2007 on Limited Companies and other laws. 
Under these conditions, the problems that raised in this study were (1) What is the basis for the emergence of a legal relationship between the limited parent company with subsidiaries in the form of a CV, and (2) How is the legal effect of the legal relationship between the limited parent company with subsidiaries in the form of $C V$.

Based from the vacuum norms contained in Article 84 paragraph (2) letter b of the latest UUPT, this study uses normative legal research. This study uses the approach of legislation and legal concept analysis. Sources of legal materials in this study consisted of primary legal materials, secondary and tertiary. Collecting of legal materials using the card system, while technical analysis of legal materials used are descriptive technique, interpretative technique, evaluative techniques, systematic techniques and argumentative techniques.

The results of this study indicate that (1) the basis of the emergence of the legal relationship between the limited parent company with subsidiaries in the form of $C V$ occurs because ownership CV of limited company (PT) as the parent company, so that PT can use their right to vote at the annual general meeting to establish a policy for the $C V$ as subsidiary, appoint members of the board of directors / supervisory board in the PT as the parent company as a managing director or supervisor in the $C V$, do the voting rights agreement with $C V$ and contracting control of $C V$ as a subsidiary; and (2) the legal effect of the legal relationship between the limited parent company with subsidiaries in the form of $C V$ when viewed from the principle of limited liability contained in Article 3 paragraph (1) of the latest UUPT, dominance between $P T$ against $C V$ does not bore legal responsibility for $P T$ in a legal relationship that occurs with third parties, but if PT convicted indications of irregularities in the financial statements in the legal relationship with $C V$ as a subsidiary, the PT may be liable to fines or criminal against his actions.

Keywords: Holding Company, Subsidiary, Legal Relationship.

* Mahasiswa Program Studi Magister Kenotariatan T.A. 2014/2015

**Pembimbing I

*** Pembimbing II

\section{Pendahuluan}

Penulisan latar belakang ini dilandasi oleh permasalahan tentang penerapan pengaturan kebijakan perusahaan induk yang berbentuk PT terhadap anak perusahaan yang berbentuk $\mathrm{CV}$.

UUPT terbaru yang berlaku saat ini tidak ada yang memberikan batasan mengenai bentuk dari anak perusahaan seperti halnya yang pada UUPT terdahulu, sehingga secara tidak langsung memberikan keleluasaan terhadap bentuk dari anak perusahaan sebagai badan usaha yang dapat berwujud badan hukum maupun bukan hukum.

Keadaan ini akhirnya memunculkan suatu celah hukum terkait dengan kekosongan norma (vacum of norm) dalam hal pelaksanaan penerapan kebijakan dari perusahaan induk yang berstatus sebagai badan hukum, yaitu PT terhadap anak perusahaan yang berbentuk bukan badan hukum, yaitu CV. Adapun yang melandasi sebagai pertimbangan-pertimbangan dari penulisan ini adalah :

Pertama, Konstruksi pda PT memiliki kemiripan dengan CV.

Kedua, Keberadaan perusahaan grup mengacu pada realitas bisnis tergabungnya perusahaan-perusahaan yang berada di bawah kendali induk perusahaan, dimana induk perusahaan bertindak sebagai pimpinan sentral yang mengarahkan kegiatan usaha anak perusahaan untuk mendukung kepentingan perusahaan grup sebagai kesatuan ekonomi. ${ }^{1}$

Ketiga, UUPT memberikan legitimasi kepada suatu Perseroan untuk memiliki saham pada perseroan lain.

Keempat, Dalam konstruksi perusahaan grup, kepemilikan perusahaan induk atas saham pada anak perusahaan dalam jumlah tertentu memberi kewenangan kepada perusahaan induk untuk bertindak sebagai pimpinan sentral yang mengendalikan anak perusahaan melalui RUPS anak perusahaan, namun hal ini menjadi permasalahan apabila bentuk anak perusahaan bukan berstatus sebagai badan hukum.

Berdasarkan uraian di atas, maka rumusan masalah dalam penelitian ini dapat dikemukakan dalam research question adalah (1) Apakah yang menjadi dasar timbulnya hubungan hukum antara perusahaan induk yang berbentuk PT dengan anak perusahaan yang berbentuk CV ? dan (2) Bagaimanakah konsekuensi atau akibat hukum dari hubungan antara perusahaan induk yang berbentuk PT dengan anak perusahaan yang berbentuk $\mathrm{CV}$ ?

\section{Metode Penelitian}

Penelitian ini merupakan penelitian hukum normatif yang beranjak dari kekosongan norma

1 Sulistiowati, 2010, Aspek Hukum dan Realitas Bisnis Perusahaan Grup di Indonesia (selanjutnya disingkat Sulistiowati I), Penerbit Erlangga, Jakarta, hal.20 
pada Pasal 84 ayat (2) huruf b UUPT terbaru yang tidak menjelaskan mengenai pemaparan bentuk bagi anak perusahaan, sehingga menimbulkan suatu celah hukum pada konstruksi perusahaan grup apabila perusahaan induk berbentuk perseroan terbatas dan anak perusahaan berbentuk persekutuan komanditer. Penelitian ini menggunakan pendekatan perundangundangan dan pendekatan analisis konsep hukum. Sumber bahan hukum dalam penelitian ini terdiri dari bahan hukum primer, bahan hukum sekunder, dan bahan hukum tertier. Teknik pengumpulan bahan hukum dalam penelitian ini adalah dengan menggunakan sistem kartu (card system). Teknik analisis bahan hukum menggunakan teknik deskriptif, interpretatif, evaluatif dan argumentatif.

\section{TEORI DAN KONSEP MENGENAI PERUSAHAAN}

\subsection{Teori Tentang Subjek Hukum}

Secara terminologis dapat disebut bahwa manusia adalah subjek hukum. walaupun demikian, perlu diingat ada perkecualiannya yaitu bukan hanya manusia saja yang mempunyai kepribadian hukum, melainkan juga perkumpulan manusia bersama-sama dapat mempunyai kemampuan untuk menjadi subjek dinamakan badan hukum. ${ }^{2}$ Bertitik tolak dari pandangan tersebut, maka dapat disimpulkan bahwa yang dapat disebut sebagai subjek hukum adalah orang (naturlijk persoon) dan badan hukum (rechtpersoon).

\subsection{Teori Tentang Badan Hukum}

Istilah badan hukum ini tidak dijabarkan secara lengkap di dalam peraturan umum ataupun KUHPdt. Istilah rechtpersoon tersebut juga tidak ditemukan dalam Bab IX Buku III KUHPdt, meskipun maksudnya antara lain mengatur rechtpersonalijkheid atau kepribadian hukum, yaitu bahwa badan hukum tersebut memiliki kedudukan sebagai subjek hukum. Hal ini dapat dilihat dari banyaknya teori-teori yang yang mengkaji keberadaan badan hukum, seperti halnya teori fiksi dari Von Savigny, teori harta kekayaan bertujuan dari Brinz, teori organ dari Von Gierke, teori leer van het ambtelijk vermogen, teori kekayaan bersama, teori kenyataan yuridis, teori dari leon duguit. Pemaparan mengenai istilah badan hukum ini bertujuan untuk memberikan kejelasan terhadap penggolongan jenis-jenis badan hukum di Indonesia.

\subsection{Konsep Tentang Perusahaan}

\subsubsection{Pengertian Tentang Perusahaan}

Dalam pemahaman Molengraaf pengertian perusahaan seperti itu adalah pengertian ekonomis. Molengraaf mengatakan perusahaan adalah keseluruhan perbuatan yang dilakukan secara terus menerus bertindak ke luar untuk

${ }^{2}$ Chidir Ali, 2011, Badan Hukum, Alumni, Bandung, hal.5

${ }^{3}$ Chidir Ali, Op.Cit, hal.14 memperoleh penghasilan dengan memperniagakan atau menyerahkan barangbarang atau mengadakan perjanjian-perjanjian perniagaan. ${ }^{4}$

Rachmadi Usman mengacu pada pengertian perusahaan menurut Undang-Undang No. 3 Tahun 1982 Tentang Wajib Daftar Perusahaan. Adapun definisi perusahaan adalah setiap bentuk usaha yang menjalankan setiap jenis usaha yang bersifat tetap dan terus menerus dan yang didirikan, bekerja serta berkedudukan dalam wilayah Negara Republik Indonesia, untuk tujuan memperoleh keuntungan dan atau laba. Rachmadi usman menilai pengertian di atas meliputi bentuk usaha (company) dan sekaligus jenis usaha (business). Oleh karena itu Perusahaan adalah "badan usaha yang menjalankan kegiatan di bidang perekonomian (keuangan, industri, dan perdagangan), yang dilakukan secara terus menerus atau teratur (regelmatig), terangterangan (openlijk), dan dengan tujuan memperoleh keuntungan dan atau laba (wintsoogmerk)."

\subsubsection{Bentuk - Bentuk Perusahaan}

Adapun bentuk-bentuk perusahaan antara lain perusahaan perorangan (Usaha Dagang (UD)), Persero (Maatschap), Perseroan Firma (Venootschap Onder Firma), Perseroan Komanditer (Commanditaire Vennootschap), dan Perseroan Terbatas (Naamloze Vennootschap).

\subsubsection{Sumber Pengaturan Hukum Perusahaan}

Sumber hukum perusahaan di Indonesia diatur dalam KUHD, Peraturan perundangundangan yang berkaitan, Kebiasaan, dan Yurisprudensi. Adapun sumber utama hukum perusahaan adalah KUHD. Hukum dagang adalah hukum perikatan yang timbul khusus dari lapangan perusahaan. Hukum dagang yang diatur dalam KUHD dan peraturan-peraturan lain di luar kodifikasi. Selain KUHD yang juga menjadi sumber hukum perusahaan adalah KUHPdt. KUHPdt merupakan hukum perdata merupakan hukum perdata umum, KUHD merupakan hukum perdata khusus. $^{6}$

\subsection{Konsep Tentang Perusahaan Grup}

3.4.1 Pengertian Perusahaan Grup

Tentang

Emmy Simanjuntak menyatakan bahwa perusahaan grup merupakan dari perusahaanperusahaan yang secara yuridis mandiri, yang kemudian membentuk satu kesatuan ekonomi

${ }^{4}$ HMN Purwosutjipto, 1985, Hukum Dagang Indonesia, Djambatan, Jakarta, hal.15-21

${ }^{5}$ Abdul R. Saliman, 2014, Hukum Bisnis Untuk Perusahaan ( Teori dan Contoh Kasus), Kencana, Jakarta, hal. 83

${ }^{6}$ Janus Sidabalok, 2012, Hukum Perusahaan (Analisis Terhadap Pengaturan Peran Perusahaan Dalam Pembangunan Ekonomi Nasional di Indonesia), Nuansa Aulia, Bandung, (selanjutnya disingkat Janus Sidabalok I), hal. 88 
yang tunduk kepada suatu pimpinan dari suatu perusahaan induk sebagai pimpinan sentral. ${ }^{7}$ Pengertian tersebut menunjukkan bahwa perusahaan grup dikonstruksikan oleh adanya keterkaitan yang terjadi diantara perusahaan induk dan perusahaan anak yang masing-masing berbadan hukum mandiri dengan implikasi induk perusahaan memiliki kekuasaan untuk bertindak sebagai pimpinan sentral yang mengendalikan dan mengkoordinasikan anak-anak perusahaan dalam suatu kesatuan ekonomi untuk mewujudkan kepentingan perusahaan grup.

\subsubsection{Pengertian Perusahaan Induk}

Tentang

Perusahaan Induk adalah perusahaan yang berbentuk PT yang menjalankan pimpinan sentral pada perusahaan grup untuk mengendalikan dan mengkoordinasikan anak perusahaan, sehingga tidak terbatas pada kepemilikan saham pada anak perusahaan saja. ${ }^{8}$ Sulistiowati pada definisi ini melakukan pemisahan pengertian antara Parent Company dengan Holding Company.

\subsubsection{Pengertian Tentang Anak Perusahaan}

Menurut UUPT terdahulu anak perusahaan yaitu :

Anak perusahaan adalah perseroan yang mempunyai hubungan khusus dengan perseroan lainnya yang terjadi karena : (1) Lebih dari 50 $\%$ (lima puluh persen) sahamnya dimiliki oleh induk perusahaannya, (2) Lebih dari $50 \%$ (lima puluh persen) suara dalam RUPS dikuasai oleh induk perusahaannya, dan atau (3) Kontrol atas jalannya perseroan, pengangkatan, dan pemberhentian direksi dan komisaris sangat dipengaruhi oleh induk perusahaannya.

\section{PENGATURAN HUBUNGAN HUKUM PERUSAHAAN INDUK BERBENTUK PERSEROAN TERBATAS DENGAN ANAK PERUSAHAAN BERBENTUK PERSEKUTUAN KOMANDITER}

\subsection{Ruang Lingkup Hubungan Hukum Perusahaan Induk dengan Anak Perusahaan}

Hukum perusahaan memberikan kedudukan terhadap suatu perseroan untuk melakukan perbuatan hukum yang berakibat kepada kepemilikan saham pada anak perusahaan, sehingga menimbulkan keterkaitan antara perusahaan induk dan perusahaan anak. Perbuatan-perbuatan hukum ini meliputi pengambilalihan saham, perjanjian joint venture, pendirian anak perusahaan, pemisahan perseroan ataupun pengalihan saham yang mana telah diatur dalam Bab VIII UUPT tentang Penggabungan, Peleburan, Pengambilalihan dan Pemisahan,

${ }^{7}$ Emmy Pangaribuan Simanjuntak, 1994, Perusahaan Kelompok (Seri Hukum Dagang Fakultas Hukum Gadjah Mada), Yogyakarta, hal.1

${ }^{8}$ Sulistiowati I,Op.Cit, hal.1 khususnya pada Pasal 122 s/d 137. Kepemilikan suatu perseroan atas saham dari perusahaan lain melahirkan kewenangan dari perseroan sebagai perusahaan induk untuk mengendalikan perusahaan lainnya. ${ }^{9}$

Dengan demikian, hal yang menjadi ruang lingkup hubungan hukum perusahaan induk dengan anak perusahaan dapat ditinjau dari :

(1) Pengakuan Yuridis terhadap Perusahaan Grup Menurut Hukum Positif di Indonesia

(2) Hubungan Perusahaan Induk dengan Anak Perusahaan Menurut UU No. 40 Tahun 2007 Tentang Perseroan Terbatas

(3) Hubungan Perusahaan Induk dengan Anak Perusahaan Menurut Doktrin

Berikut adalah penjelasan yang merupakan bagian dari ruang lingkup hubungan hukum perusahaan induk dengan anak perusahaan :

4.1.1 Pengakuan Yuridis terhadap Perusahaan Grup Menurut Hukum Positif di Indonesia

Belum adanya pengakuan yuridis terhadap status perusahaan grup sebagaimana badan hukum lainnya, menyebabkan UUPT terdahulu maupun peraturan perundang-undangan lainnya masih mempertahankan pengakuan yuridis formal terhadap status badan hukum perusahaan induk dan anak perusahaan sebagai subjek hukum mandiri. Namun setelah diundangkannya UUPT terbaru dan berlakunya Pasal 84 ayat (2) huruf b, maka memunculkan suatu kekosongan hukum bagi suatu anak perusahaan untuk tidak berbentuk badan hukum mandiri. Hanya saja untuk melakukan kegiatan ekonomi yang membutuhkan suatu kepastian hukum, maka anak perusahaan ini harus dapat berubah kedudukannya menjadi badan hukum mandiri melalui suatu penetapan pengadilan.

4.1.2 Hubungan Perusahaan Induk dengan Anak Perusahaan Menurut UU No. 40 Tahun 2007 Tentang Perseroan Terbatas

Menurut hemat penulis hubungan antara perusahaan induk anak perusahaan dalam konstruksi perusahaan grup disebabkan oleh halhal berikut ini:

a. Kepemilikan saham dari anak perusahaan oleh perusahaan induk

b. Rapat umum pemegang saham

c. Keterkaitan melalui perjanjian hak bersuara

d. Keterkaitan melalui kontrak

4.1.3 Hubungan Perusahaan Induk dengan Anak Perusahaan Menurut Doktrin

Sebagaimana yang dipaparkan pada konsep perusahaan di Bab II, maka pengaturan terhadap perusahaan induk dan anak perusahaan yang tidak bersama-sama berstatus badan hukum, maka

${ }^{9}$ Sulistiowati I, Op.Cit, hal. 95 
pengaturannya harus dikembalikan kepada peraturan perundangan pelaksananya masingmasing.

Terhadap perusahaan induk yang berbadan hukum mandiri berlaku prinsip hukum yang menjadi pondasi dasar perusahaan induk yang berbentuk perseroan terbatas, yang meliputi pertanggungjawaban terbatas dan pengesahan status badan hukum perseroan sebagai subjek hukum mandiri atau separate legal entity, dan limited liability.

\subsection{Kerangka Pengaturan \\ Hubungan Perusahaan Induk Berbentuk Perseroan Terbatas dengan Anak Perusahaan Berbentuk Persekutuan Komanditer}

Perusahaan grup ialah merupakan gabungan atau susunan dari perusahaan-perusahaan yang secara yuridis mandiri, yang terkait satu sama lainnya begitu erat, sehingga membentuk satu kesatuan ekonomi yang tunduk kepada satu pimpinan dari suatu perusahaan induk sebagai pimpinan sentral. ${ }^{10}$ Sehingga menurut hemat penulis, apabila hal ini dikaitkan dengan hubungan perusahaan induk dan anak perusahaan pengertian di atas menunjukkan bahwa konstruksi perusahaan grup ditimbulkan oleh adanya keterkaitan dalam hal ini antara perusahaan induk dan anak perusahaan yang berbadan hukum mandiri. Perusahaan induk sebagai pimpinan sentral yang mengendalikan dan mengkoordikasikan anak perusahaan dalam suatu kesatuan manajemen bagi terciptanya tujuan kolektif perusahaan grup sebagai kesatuan ekonomi.

Mengenai kewenangan perusahaan induk untuk mengendalikan anak perusahaan maka perusahaan induk dianggap menjalankan fungsi sebagai holding company. Munir Fuady mengartikan holding company adalah suatu perusahaan yang bertujuan untuk memiliki saham dalam satu atau lebih perusahaan lain dan/atau mengatur satu atau lebih perusahaan lain tersebut. ${ }^{11}$

Subjek hukum pada KUHPerdata terbagi menjadi dua, yaitu orang dan badan hukum. Orang oleh subekti diartikan sebagai pembawa hak atau subjek di dalam hukum dimulai sejak dalam kandungan sampai saat dia meninggal. Sedangkan badan hukum diartikan sebagai perkumpulan hukum yang dapat memiliki hak dan melakukan perbuatan hukum seperti subjek hukum lainnya, yaitu orang. Apabila merujuk kembali pada pengertian CV dalam Pasal 19 KUHD sebagaimana yang dipaparkan hal. 22

${ }^{10}$ Emmy Pangaribuan Simanjuntak, Op.Cit,

${ }^{11}$ Munir Fuady, 1999, Hukum Perusahaan Dalam Paradigma Hukum Bisnis, Citra Aditya Bakti, Bandung (selanjutnya disingkat Munir Fuady III), hal. 84 . sebelumnya di atas, maka terdapat dua istilah subjek hukum yang dipergunakan di dalamnya definisi CV, yaitu orang dan persero. Orang dalam KUHPerdata diartikan sebagai subjek hukum murni dan persero dalam KUHPerdata merujuk pada istilah perseroan, maka dapat diartikan dalam kedudukannya sebagai badan hukum, sehingga berdasarkan hal itu dapat ditarik kesimpulan bahwa CV dapat didirikan oleh orang perorangan maupun perseroan yang berbentuk badan hukum.

Keterkaitan antara perusahaan induk yang berbentuk badan hukum terhadap anak perusahaan yang bukan berbentuk badan hukum membawa akibat terhadap PT dalam menjalankan kebijakannya sebagai perusahaan induk terhadap CV sebagai anak perusahaan dengan menempatkan salah satu organ perseroannya sebagai sekutu komanditer yang merupakan pemegang saham dalam CV. Organ perseroan yang ditunjuk sebagai pemegang saham terbanyak dalam CV ini senantiasa menjalankan kebijakan yang diputuskan pada RUPS perusahaan induk, namun hanya sebatas dari jumlah saham yang dimilikinya saja.

\subsection{Hubungan Hukum antara Perusahaan Induk Berbentuk Perseroan Terbatas dengan Anak Perusahaan Berbentuk Persekutuan Komanditer}

Istilah mengenai holding company atau parent company dalam kaitannya dengan perusahaan induk tidak banyak disinggung dalam UUPT terbaru. Pengaturannya dapat ditemukan dalam Pasal 7 ayat (1), ayat (2), Pasal 48 ayat (2), dan Pasal 84 ayat (2) UUPT terbaru. UUPT terbaru tidak mengakui eksistensi perusahaan grup melainkan hanya mengenal adanya keterkaitan antara perusahaan induk dan perusahaan anak. Keterkaitan antara perusahaan induk dan perusahaan anak tidak menghapus status badan hukum mandiri yang dimiliki oleh masing-masing perusahaan tersebut.

Belum adanya pengaturan mengenai perusahaan grup menyebabkan peraturan perundang-undangan tidak ada yang mengatur mengenai konstruksi perusahaan grup selain pada hukum perseroan. Kerangka pengaturan mengenai keterkaitan antara perusahaan induk dan anak perusahaan yang masih menggunakan pendekatan perseroan tunggal dalam UUPT terbaru menimbulkan kontradiksi dengan realitas bisnis perusahaan grup yang ditandai oleh adanya pengendalian saham anak perusahaan oleh perusahaan induk. Adapun substansi dalam UUPT terbaru mengizinkan suatu perseroan sebagai perusahaan induk untuk melakukan pengambilalihan saham pada perusahaan lain, baik melalui pendirian, pengambilalihan saham, maupun pemisahan usaha sebagaimana yang terdapat dalam Bab VIII UUPT terbaru, yaitu pada Pasal 122 s/d 137. Kepemilikan saham dalam anak perusahaan oleh perseroan sebagai 
perusahaan induk menjadi sebab dari timbulnya keterkaitan antara perusahaan induk dan anak perusahaan, sehingga perusahaan induk memiliki kekuasaan untuk bertindak sebagai pimpinan sentral yang mengendalikan dan mengkoordinasikan anak-anak perusahaannya dalam mendukung tercapainya tujuan kolektif perusahaan grup sebagai kesatuan ekonomi.

Hubungan ekonomi yang terjadi di antara perseroan sebagai perusahaan induk yang berkedudukan sebagai badan hukum mandiri dengan CV sebagai anak perusahaan sebagai subjek hukum mandiri menciptakan suatu hubungan hukum diantara keduanya pada konstruksi perusahaan grup, adapun hal tersebut dapat ditinjau dari dua aspek, yaitu:

1) Pengawasan Perusahaan Induk Berbentuk Perseroan Terbatas terhadap Anak Perusahaan Berbentuk Persekutuan Komanditer

2) Pengendalian Perusahaan Induk Berbentuk Perseroan Terbatas terhadap Anak Perusahaan Berbentuk Persekutuan Komanditer

Berikut penjabaran dari masing-masing aspek tersebut.

\subsubsection{Pengawasan Perusahaan Induk Berbentuk Perseroan Terbatas terhadap Anak Perusahaan Berbentuk Persekutuan Komanditer}

Kewenangan suatu perseroan sebagai perusahaan induk untuk mengendalikan anak perusahaannya yang berbentuk CV menjadi alasan dari lahirnya pimpinan sentral dalam perusahaan grup yang dapat mengarahkan keseluruhan kepentingan anggota kelompok untuk mendukung kepentingan perusahaan grup, selain itu konstruksi perusahaan grup juga memudahkan perusahaan yang bersangkutan untuk mengatasi berbagai permasalahan menyangkut operasional perusahaan dalam wilayah yurisdiksi yang berbeda. $^{12}$

Dengan mengacu pada alasan tersebut, maka pembentukan atau pengembangan konstruksi perusahaan grup merupakan strategi pertumbuhan eksternal untuk mengakomodasi ekspansi bisnis maupun memperoleh posisi strategis di pasar dengan melakukan integrasi vertikal atau horizontal maupun divesifikasi usaha melalui kerjasama dengan perusahaan lain atau mengalokasikan sebagian kegiatan usaha pada perusahaan lain. Berbagai kegiatan bisnis perusahaan grup berimplikasi kepada terbentuknya perusahaan grup dengan skala yang

12 Sulistiowati, 2013, Tanggung Jawab Hukum Pada Perusahaan Grup di Indonesia, Erlangga, Jakarta, (selanjutnya disingkat Sulistiowati II) hal. 38-39 lebih besar dan memiliki konstruksi perusahaan grup yang kompleks dan secara kolektif terikat pada suatu kesatuan ekonomi. ${ }^{13}$

Berdasarkan pemaparan tersebut, apabila ditinjau dari segi manajemen strategis, penyatuan orientasi kegiatan usaha dari perusahaan induk yang berbentuk perseroan bertujuan untuk melakukan pengawasan terhadap anak perusahaannya yang berbentuk CV. Adapun analogi yang digunakan menggunakan tiga tingkatan strategis yang bersifat hierarkis, yaitu :

a. Strategi korporasi merupakan strategi pada tingkatan perusahaan grup. Perusahan induk merumuskan strategi korporasi, termasuk tujuan dan cara pencapaiannya yang dijabarkan menjadi strategi bisnis dari anakanak perusahaan.

b. Strategi bisnis anak-anak perusahaan ini ditujukan untuk mendukung kepentingan perusahaan grup sebagaimana yang diformulasikan dalam strategi korporasi.

c. Direksi dan anak perusahaan menjabarkan strategi fungisional untuk masing-masing fungsi yang meliputi keuangan, produksi, pemasaran dan sumber daya manusia untuk mendukung strategi bisnis anak perusahaan. ${ }^{14}$

Penjabaran mengenai strategi bisnis di atas menunjukkan bahwa kapasitas perseroan sebagai perusahaan induk bertujuan untuk melakukan pengawasan dalam hubungannya dengan pengendalian kegiatan dari anak perusahaan. Perusahaan induk akan merumuskan strategi perusahaan grup yang dijabarkan mengenai startegi pada tingkat anak perusahaan, sedangkan direksi yang ditempatkan oleh perusahaan induk di dalam CV sebagai anak perusahaan menjalankan strategi bisnis sebagaimana yang ditetapkan perseroan.

\subsubsection{Pengendalian Perusahaan Induk Berbentuk Perseroan Terbatas terhadap Anak Perusahaan Berbentuk Persekutuan Komanditer}

Pada prakteknya, pengendalian perusahaan induk terhadap anak perusahaan ini tidak terbatas hanya pada kepemilikan saham mayoritas, tetapi juga dominasi induk terhadap anak perusahaan. Bahkan pengendalian perusahaan induk terhadap anak perusahaan ini tidak terbatas pada kebijakan keuangan saja, tetapi juga mencakup kebijakan dan praktik bisnis yang terkait dengan keseluruhan transaksi anak perusahaan. ${ }^{15}$
${ }^{13}$ Ibid, hal. 39
${ }^{14}$ Ibid.
${ }^{15}$ Sulistiowati I, Op.Cit, hal.135 
Fakta pengendalian perusahaan induk terhadap anak perusahaan dalam konstruksi perusahaan grup yang mempengaruhi kemandirian anak perusahaan dapat dianalisis dari adanya beberapa aspek berikut ini :

1. Perusahaan Induk dapat mengangkat anggota direksi dan/atau dewan komisaris anak perusahaan

2. Perusahaan induk mempengaruhi kebijakan anak perusahaan

3. Perusahaan induk mempengaruhi kepentingan usaha anak perusahaan

Pengendalian perusahaan induk yang berbentuk PT terhadap anak perusahaan yang berbentuk CV diperlukan untuk menjamin keberlangsungan dari perusahaan grup. Pengendalian tersebut tidak menghapuskan kemandirian dari anak perusahaan, hanya saja kebijakan strategis dari perusahaan induklah yang harus diutamakan.

\section{AKIBAT HUKUM YANG DITIMBULKAN DARI HUBUNGAN ANTARA PERUSAHAAN INDUK BERBENTUK PERSEROAN TERBATAS DENGAN ANAK PERUSAHAAN BERBENTUK PERSEKUTUAN KOMANDITER}

\subsection{Tanggung Jawab Perusahaan Grup Sebagai Kesatuan Ekonomi}

Keterkaitan antara perusahaan induk dan anak perusahaan pada konstruksi perusahaan grup berlandaskan pada dominasi kepemilikan saham dari anak perusahaan oleh perusahaan induk yang mengakibatkan kedudukan dari perusahaan induk sebagai pimpinan sentral pada perusahaan grup. Oleh karena kedudukannya tersebut, maka perusahaan induk memiliki hak dalam mengendalikan dan mengkoordinasikan anakanak perusahaan dalam mendukung tujuan perusahaan grup sebagai kesatuan ekonomi.

Dengan demikian, maka hal yang menjadi tanggung jawab perusahaan grup sebagai kesatuan ekonomi dapat ditinjau dari :

a) Hubungan Antara HAM Ekonomi

Dan Pengendalian Perusahaan Induk

Terhadap Anak Perusahaan Dalam

Mewujudkan Kesatuan Ekonomi

b) Penerapan Prinsip Good Corporate Governance Dalam Langkah

Mewujudkan Kesatuan Ekonomi

Pada Perusahaan Grup

Berikut adalah penjabaran dari hal yang menjadi bagian dari tanggung jawab perusahaan grup sebagai kesatuan ekonomi :

5.1.1 Hubungan Antara HAM Ekonomi Dan Pengendalian Perusahaan Induk Terhadap Anak Perusahaan Dalam Mewujudkan Kesatuan Ekonomi

Pengendalian perusahaan induk terhadap anak perusahaan dalam pelaksanaannya harus mengacu pada HAM Ekonomi untuk menghindari terjadinya kesewenang-wenangan yang dilakukan oleh perusahaan induk terhadap anak perusahaan terkait dengan dominasi yang dimilikinya sebagai pimpinan sentral pada konstruksi perusahaan grup. Pemaparan mengenai HAM ekonomi ini dimuat dalam UUD 1945, yaitu pada Pasal 27 ayat (2), Pasal 28 D ayat (2) dan Pasal 33. Perusahaan induk dalam kewenangannya untuk melakukan pengendalian terhadap anak perusahaan pada konstruksi perusahaan grup harus senantiasa memberikan perlakuan yang adil dan layak bagi anak perusahaan sebagaimana yang dimuat pada isi Pasal $28 \mathrm{D}$ ayat (2) UUD 1945 untuk mendukung tercapainya penerapan jaminan terhadap HAM Ekonomi bagi anak perusahaan. Adapun untuk menjamin keadilan serta kelayakan dari kegiatan induk perusahaan sebagai pimpinan sentral dari perusahan grup, maka perusahaan induk harus menerapkan asas demokrasi ekonomi sebagaimana yang dimuat dalam Pasal 33 ayat (3) UUD 1945 agar stabilitas kegiatan perekonomian terkait pengendalian yang dilakukan antara perusahaan induk terhadap anak perusahaan di dalam suatu konstruksi perusahaan grup dapat berjalan dengan baik.

5.1.2 Penerapan Prinsip Good Corporate Governance Dalam Langkah Mewujudkan Kesatuan Ekonomi Pada Perusahaan Grup

Perusahaan grup dalam kedudukannya sebagai salah satu penggerak perekonomian di Indonesia sebagian besar menggunakan konstruksi piramida dengan ciri yaitu perusahaan induk menggunakan prinsip limited liability sebagaimana yang terdapat pada isi Pasal 3 ayat (1) UUPT terbaru dalam pelaksanaan kegiatan bisnis dengan hubungannya terhadap pihak ketiga yang memiliki keterkaitan dengan anak perusahaan. Selain itu ciri lainnya ialah semakin banyak anak perusahaan yang dimiliki oleh perusahaan induk, maka tanggung jawab perusahaan induk semakin terbatas. Oleh karena itu menurut hemat penulis untuk menemukan jawaban terhadap permasalahan mengenai kemandirian dan pengendalian dari anak perusahaan, maka dapat dilakukan pendekatan melalui prinsip GCG (Good Corporate Governance). ${ }^{16}$

\subsection{Tanggung Jawab Hukum Perusahaan Induk Berbentuk Perseroan Terbatas terhadap Anak Perusahaan Berbentuk Persekutuan Komanditer}

Globalisasi dan liberalisasi ekonomi dunia mempunyai akibat terhadap ekonomi nasional, pemerintahan dan sistem hukum, juga menimbang peraturan-peraturan internasional, hukum asing, praktek-praktek bisnis, sebelum mereka dapat menetapkan dan memformulasikan kebijakan dan strateginya yang selanjutnya membangun hukum

${ }^{16}$ Sulistiowati II, Op.Cit, hal.167 
dan peraturan-peraturan. ${ }^{17}$ Kesenjangan antara realitas bisnis dan aspek yuridis pada perusahaan grup menimbulkan ketegangan antara perusahaan grup secara yuridis dan kesatuan ekonomi, sehingga berimplikasi terhadap munculnya kemandirian yuridis dari perseroan sebagai perusahaan induk dan anak perusahaan yang berbentuk CV yang membawa dampak bagi ketidakmandirian secara ekonomi bagi CV. Kemandirian yuridis perusahaan induk dan anak perusahaan menyebabkan perusahaan induk tidak bertanggung jawab atas perbuatan hukum dari anak perusahaan yang berbadan hukum mandiri, sedangkan ketidakmandirian secara ekonomi menyebabkan pengurusan anak perusahaan tidak hanya untuk kepentingan bagi anak perusahaan saja. $^{18}$

Berdasarkan pemaparan tersebut, maka aspek-aspek dalam tanggung jawab hukum perusahaan induk berbentuk perseroan terbatas terhadap anak perusahaan berbentuk persekutuan komanditer dapat ditinjau dari :

a) Dualitas Antara Perusahaan Induk Berbentuk Perseroan Terbatas terhadap Anak Perusahaan Berbentuk Persekutuan Komanditer berdasarkan Prinsip Limited Liability

b) Akibat Hukum Perusahaan Induk Berbentuk Perseroan Terbatas terhadap Anak Perusahaan Berbentuk Persekutuan Komanditer dalam Hubungannya dengan Pihak Ketiga

Berikut adalah penjabaran dari aspek-aspek yang menjadi bagian dalam tanggung jawab hukum perusahaan induk berbentuk perseroan terbatas :

5.2.1 Dualitas Antara Perusahaan Induk Berbentuk Perseroan Terbatas terhadap Anak Perusahaan Berbentuk Persekutuan Komanditer Berdasarkan Prinsip Limited Liability

Dualitas terhadap anak perusahaan berbentuk persekutuan komanditer Dualitas PT sebagai perusahaan induk sebagai pemegang saham atas CV yang merupakan anak perusahaannya tidak berimplikasi terhadap lahirnya tanggung jawab PT atas perbuatan hukum CV. Pada prinsipnya, perusahaan induk maupun anak perusahaanya tidak memiliki kepentingan dengan hak dan kewajiban dari anak perusahaan dalam kaitannya terhadap hubungan dengan pihak ketiga, sehingga perusahaan induk tidak bertanggung jawab dan tidak memperoleh

17 Sunaryati Hartono, 2000, Business and The Legal Profession in an Age of Computerization and globalization, Yayasan Hak Asasi Manusia, Demokrasi dan Supremasi Hukum, PT. Alumni, Bandung (selanjutnya disebut Sunaryati Hartono II)

${ }^{18}$ Sulistiowati II, Op.Cit, hal.53 hak dari hubungan yang dilakukan oleh anak perusahaan dengan pihak ketiga. Oleh karena itu, perusahaan induk tidak bertanggung jawab terhadap perbuatan hukum yang dilakukan oleh anak perusahaan, sehingga anak perusahaan harus bertanggung jawab secara mandiri berdasarkan kewajibannya dengan pihak ketiga. ${ }^{19}$

Pada prinsipnya, PT dalam kedudukannya sebagai perusahaan induk pada konstruksi perusahaan grup dapat dikenakan tanggung jawab hukum atas kerugian yang diterima oleh pihak ketiga sebagai akibat hukum dari $\mathrm{CV}$ yang menjalankan kebijakan dari PT. Namun apabila ditinjau dari prinsip limited liability yang terdapat dalam hukum perseroan, maka dominasi perusahaan induk terhadap anak perusahaannya tidaklah berimplikasi terhadap lahirnya tanggung jawab hukum dari perusahaan induk yang dalam hal ini adalah PT kepada pihak ketiga .

5.2.2 Akibat Hukum Perusahaan Induk Berbentuk Perseroan Terbatas terhadap Anak Perusahaan Berbentuk Persekutuan Komanditer dalam Hubungannya dengan Pihak Ketiga

Merujuk kepada prinsip piercing the corporate veil yang telah dipaparkan sebelumnya di atas, maka apabila PT yang merupakan pimpinan sentral dari perusahaan grup terbukti terlibat dalam hubungan hukum yang dilakukan oleh CV sebagai anak perusahaan dengan pihak ketiga maupun tindakan lainnya yang menimbulkan kerugian bagi perusahaan grup, namun PT tidak mau bertanggung jawab dengan berpegang pada prinsip tanggung jawab terbatas dari prinsip limited liability pada Pasal 3 ayat (1) UUPT, maka hal ini dapat menimbulkan tanggung jawab hukum bagi PT yang berupa sanksi pidana berupa penjara maupun perdata yang berupa ganti rugi yang dibebankan kepada pengurus dalam hal ini yaitu organ perusahaan pada PT.

\section{Kesimpulan dan Saran}

\subsection{Kesimpulan}

Berdasarkan pembahasan pada bab-bab yang telah diuraikan sebelumnya, maka dapat ditarik kesimpulan, bahwa:

1. Dasar timbulnya hubungan hukum antara perusahaan induk yang berbentuk PT dengan anak perusahaan yang berbentuk CV terjadi karena adanya kepemilikan saham dari CV terhadap PT sebagai perusahaan induk, sehingga PT dapat menggunakan hak suaranya dalam RUPS untuk menetapkan kebijakan bagi CV sebagai anak perusahaan, mengangkat anggota direksi/dewan pengawas dalam PT sebagai perusahaan induk sebagai direktur utama atau pengawas dalam CV, melakukan perjanjian

${ }^{19}$ Sulistiowati II, Op.Cit, hal. 54-56 
hak bersuara dengan CV dan melakukan kontrak kendali terhadap CV sebagai anak perusahaan.

2. Konsekuensi hukum dari hubungan hukum antara perusahaan induk yang berbentuk PT dengan anak perusahaan yang berbentuk $\mathrm{CV}$ apabila ditinjau dari prinsip limited liability yang terdapat dalam Pasal 3 ayat (1) UUPT terbaru, maka dominasi antara PT terhadap CV tidak melahirkan tanggung jawab hukum bagi PT dalam hubungan hukum yang terjadi dengan pihak ketiga, namun apabila PT terbukti melakukan indikasi-indikasi penyimpangan pada laporan keuangan dalam hubungan hukumnya dengan CV sebagai anak perusahaan, maka PT dapat dikenakan sanksi berupa denda atau pidana terhadap perbuatannya tersebut .

\subsection{Saran}

Adapun saran yang dapat diberikan terkait dengan penelitian ini ialah :

1. Disarankan terhadap Pemerintah khususnya dalam hal ini DPR bersama-sama Presiden yang memiliki kewenangan untuk membuat peraturan perundangundangan agar secepatnya melakukan revisi terhadap UUPT terbaru yaitu Undang-Undang No. 40 Tahun 2007 Tentang Perseroan Terbatas, khususnya dalam Pasal 84 ayat 2 huruf (b) yang tidak mengatur mengenai anak perusahaan.

2. Disarankan terhadap pemerintah yang dalam hal ini yaitu DPR bersama-sama Presiden yang memiliki wewenang membentuk peraturan perundang-undangan untuk secepatnya menyusun dan mengesahkan KUHPdt yang baru, karena KUHPdt yang berlaku saat ini sudah tidak dapat mengakomodir kepentingan-kepentingan dalam mengatur hubungan antara orang perorangan dan badan hukum.

\section{DAFTAR PUSTAKA}

\section{Buku}

Diantha, I Made Pasek, 2016, Metodologi Penelitian Hukum Normatif, Jakarta, Prenada Media Group.

Fuady, Munir, 1999, Hukum Perusahaan Dalam Paradigma Hukum Bisnis, Bandung, Citra Aditya Bakti.

Hartono, Sunaryati, 1982, Hukum Ekonomi Pembangunan Indonesia, Bandung, Bina Cipta.

Pangaribuan, Emmy Simanjuntak, 1994, Perusahaan Kelompok (Seri Hukum Dagang Fakultas Hukum Gadjah Mada), Yogyakarta.

Purwosutjipto, HMN, 1985, Hukum Dagang Indonesia, Jakarta, Djambatan.

Saliman, Abdul R., 2014, Hukum Bisnis Untuk Perusahaan ( Teori dan Contoh Kasus), Jakarta, Kencana.

Sidabalok, Janus, 2012, Hukum Perusahaan (Analisis Terhadap Pengaturan Peran Perusahaan Dalam Pembangunan Ekonomi Nasional di Indonesia), Bandung, Nuansa Aulia.

Sulistiowati, 2010, Aspek Hukum dan Realitas Bisnis Perusahaan Grup di Indonesia, Jakarta, Penerbit Erlangga 2013, Tanggung Jawab Hukum Pada Perusahaan Grup di Indonesia, Jakarta, Erlangga.

\section{Peraturan Perundang-Undangan}

Undang-Undang Nomor 40 Tahun 2007 Tentang Perseroan Terbatas (Lembaran Negara Republik Indonesia Tahun 2007 Nomor 106, Tambahan Lembaran Negara Republik Indonesia Nomor 4756)

$$
* * * * *
$$

